\title{
Respon Oksigen Terlarut Terhadap Pencemaran dan Pengaruhnya Terhadap Keberadaan Sumber Daya Ikan di Sungai Citarum
}

\section{Dissolved Oxygen Response Againts Pollution and The Influence of Fish Resources Existence in Citarum River}

\author{
YAYUK SUGIANTI DAN LISMINING PUJIYANI ASTUTI \\ Balai Riset Pemulihan Sumberdaya Ikan, Kementerian Kelautan dan Perikanan \\ ysugianti@yahoo.com
}

\begin{abstract}
The concentration of dissolved oxygen (DO) be the most attention parameter because can reflect the water quality and the health of aquatic ecosystems. Along the main flow of Citarum river conditions are already heavily polluted due to waste input both household and urban waste, industrial waste, agricultural waste and livestock also, this conditions causes disruption for organism that are inside, one of them is fish. The purpose of this study was to determine changes in water quality due to pollution through the distribution pattern of the DO concentration by performing simulations using models Streeter \& Phelps and their effects on fish life in the Citarum River. The results showed the high value of BOD in Citarum River led to a DO decrease, which indicates that this river has been under pressure utilization that exceeds the carrying capacity. This condition affects the presence of fish in Citarum river, where there has been a reduction the types of fish. Only fish that are resistant to low DO conditions that can survive in Citarum river.
\end{abstract}

Keywords: dissolved oxygen, Streeter Phelps model, Citarum River

\begin{abstract}
ABSTRAK
Konsentrasi oksigen terlarut (DO) menjadi parameter yang paling banyak mendapat perhatian karena mencerminkan kualitas air dan kesehatan suatu ekosistem perairan. Sepanjang aliran sungai utama Citarum kondisi perairannya sudah tercemar berat diakibatkan masukan limbah, baik itu limbah rumah tangga dan perkotaan, limbah industri, juga limbah pertanian dan peternakan, kondisi ini menyebabkan gangguan bagi organisme yang ada di dalamnya salah satunya adalah ikan. Tujuan penelitian ini adalah mengetahui perubahan kualitas perairan akibat pencemaran melalui pola sebaran konsentrasi DO dengan melakukan simulasi menggunakan model Streeter \& Phelps dan pengaruhnya terhadap kehidupan ikan di Sungai Citarum. Hasil penelitian menunjukkan tingginya nilai BOD di Sungai Citarum menyebabkan penurunan DO, yang mengindikasikan bahwa sungai ini telah mengalami tekanan pemanfaatan yang melebihi daya dukungnya. Kondisi ini berpengaruh pada keberadaan ikan di Sungai Citarum, dimana telah terjadi pengurangan jenis-jenis ikan. Hanya ikan-ikan yang tahan terhadap kondisi DO rendah yang bisa bertahan hidup di Sungai Citarum.
\end{abstract}

Kata kunci: oksigen terlarut, model Streeter Phelps, Sungai Citarum.

\section{PENDAHULUAN}

\subsection{Latar Belakang}

Parameter fisika-kimia air seperti konsentrasi oksigen terlarut (DO), suhu, dan total padatan tersuspensi (TSS), adalah beberapa parameter yang paling banyak mendapat perhatian karena mencerminkan kualitas air dan kesehatan suatu ekosistem perairan ${ }^{(1,2,3)}$. Batas konsentrasi minimum serta peran DO bagi ekosistem perairan mencerminkan kemampuan badan air dalam menyesuaikan diri dengan kehadiran beban pencemar ${ }^{(4,5,6)}$. Suhu air sendiri memegang peranan penting pada proses biologis dan kimia organisme perairan seperti metabolisme dan reaksi-reaksi tertentu dalam suatu perairan ${ }^{(4,7)}$, sedangkan TSS adalah padatan tersuspensi di dalam air berupa bahanbahan organik dan inorganik, dapat mengurangi penetrasi cahaya matahari ke dalam badan air, dan menyebabkan gangguan bagi organisme yang ada didalamnya salah satunya adalah ikan.

DO sangat berpengaruh terhadap kehidupan ikan, terutama untuk pertumbuhan, memperbaiki jaringan dan reproduksi(8). Sumber DO dapat berasal dari difusi oksigen yang terdapat di atmosfer (sekitar 35\%) dan aktivitas fotosintesis oleh tumbuhan air dan fitoplankton ${ }^{(9)}$. Ikan dapat 
hidup di dalam air dan mengkonsumsi oksigen karena ikan mempunyai insang. DO di dalam air akan berdifusi kedalam sel-sel insang ke jaringan sebelah dalam dari badannya ${ }^{(10)}$. Kebutuhan DO minimum untuk ikan air tawar tropis $\pm 5 \mathrm{mg} / \mathrm{l}$ (80\% saturasi), sedangkan untuk ikan laut tropis $\pm 5 \mathrm{mg} / \mathrm{l}\left(75 \%\right.$ saturasi) ${ }^{(11)}$. Ikan-ikan yang gesit umumnya lebih banyak membutuhkan oksigen, sementara ikan lele dan gurame termasuk jenis ikan yang mampu hidup di perairan dengan kandungan DO sedikit, karena ikan ini mempunyai pernafasan tambahan yang memungkinkan untuk mengambil oksigen dari udara di luar air ${ }^{(12) .}$

Sungai Citarum merupakan sungai terbesar di wilayah Provinsi Jawa Barat yang mengalir sepanjang $297 \mathrm{~km}$. Sungai ini dimanfaatkan pula sebagai tempat pembuangan limbah cair, baik itu limbah rumah tangga dan perkotaan, limbah industri, juga limbah pertanian dan peternakan $^{(13)}$. Hasil penelitian $\mathrm{BP} 2 \mathrm{KSI}^{(14)}$ terhadap sejumlah data kualitas air (fisika dan kimia) di DAS Citarum menunjukkan bahwa berdasarkan metode STORET sepanjang aliran sungai utama Citarum kondisi perairannya sudah tercemar berat. Kondisi ini apabila terus berlangsung akan mempengaruhi kualitas dan fungsi ekologis dari sungai, terutama untuk sumber bahan baku air bersih. Oleh karena itu menjaga kelestarian dan mutu sumber daya air Sungai Citarum adalah hal yang harus segera ditindak lanjuti.

Mengacu pada model matematika yang dikembangkan Streeter \& Phelps ${ }^{(15)}$, konsentrasi DO bersifat sebagai respon kualitas air, sedangkan suhu, BOD dan TSS bersifat sebagai prediktor.

\subsection{Tujuan Penelitian}

Tujuan penelitian ini adalah mengetahui perubahan kualitas air akibat pencemaran melalui pola sebaran konsentrasi DO dengan melakukan simulasi menggunakan model Streeter \& Phelps dan pengaruhnya terhadap kehidupan ikan di Sungai Citarum.

\section{BAHAN DAN METODE}

\subsection{Lokasi dan Waktu Penelitian}

Kegiatan penelitian dilaksanakan pada bulan Maret dan Juni 2016 di Sungai Citarum (Gambar 1; Tabel 1). Pembagian lokasi penelitian berdasarkan pada pola penggunaan lahan yang ada dengan tetap memperhatikan kemudahan akses, biaya dan waktu sehingga ditentukan titik yang mewakili kualitas air sungai.

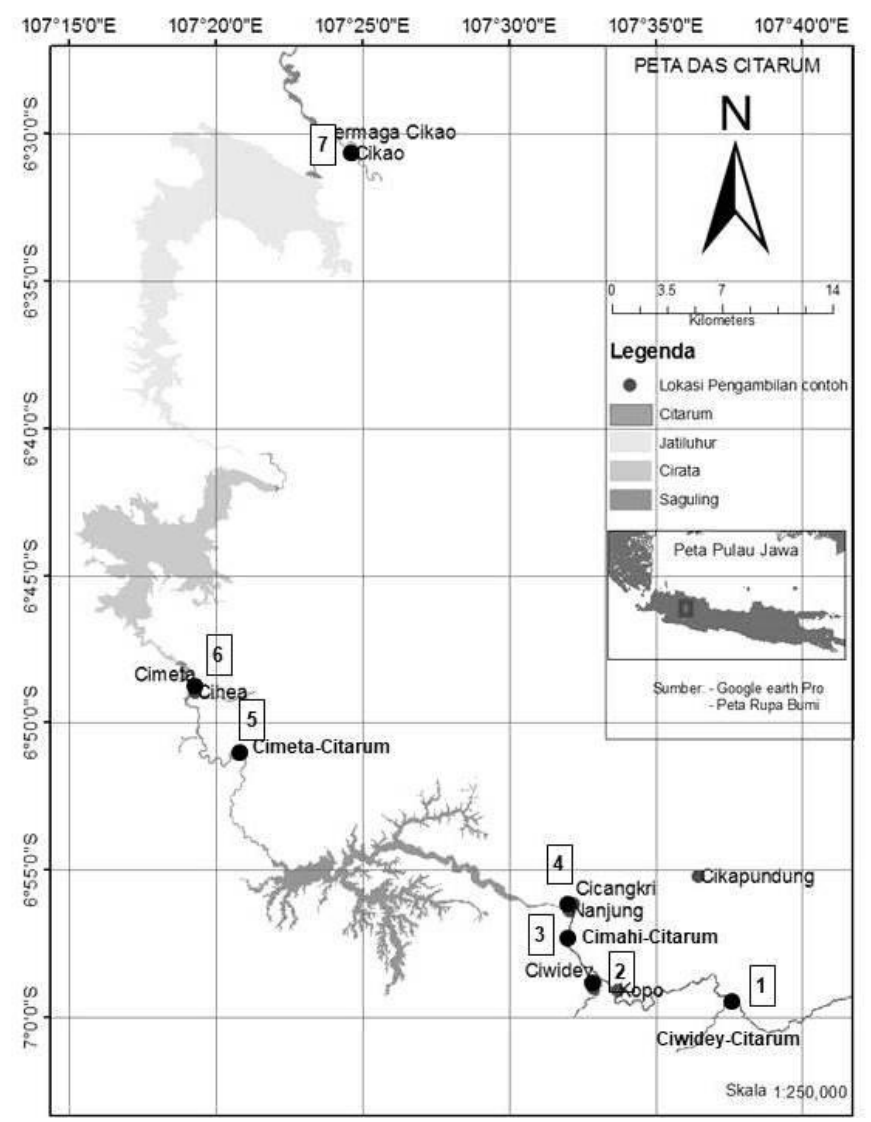

Gambar 1. Peta lokasi penelitian 
Tabel 1. Karakteristik fisik dan posisi geografi stasiun penelitian

\begin{tabular}{|c|c|c|c|}
\hline No & Nama Lokasi & $\begin{array}{c}\text { Posisi } \\
\text { Geografis }\end{array}$ & Keterangan \\
\hline 1 & Sungai Ciwidey Citarum & $\begin{array}{r}-6,9851 \text { LS } \\
107,5625 \text { BT }\end{array}$ & $\begin{array}{l}\text { - Berada di daerah perkotaan dan } \\
\text { pemukiman } \\
\text { - Di sepanjang sepadan sungai } \\
\text { terdapat rerumputan tinggi dan } \\
\text { sampah penduduk }\end{array}$ \\
\hline 2 & Sungai Ciwidey & $\begin{array}{r}-6,9837 \text { LS } \\
107,5484 \text { BT }\end{array}$ & $\begin{array}{l}\text { - Berada di daerah perkotaan } \\
\text { - Di sepanjang sepadan sungai } \\
\text { terdapat rerumputan tinggi dan } \\
\text { kebun penduduk }\end{array}$ \\
\hline 3 & Sungai Cimahi Citarum & $\begin{array}{r}-6,9399 \text { LS } \\
107,5351 \text { BT }\end{array}$ & $\begin{array}{l}\text { - Berada di daerah pemukiman } \\
\text { penduduk dan pabrik } \\
\text { - Sepadan sungai sudah ditembok } \\
\text { - Di aliran sungai terdapat sampah } \\
\text { rumah tangga }\end{array}$ \\
\hline 4 & Sungai Cimahi Cicangkri & $\begin{array}{r}-6,9362 \text { LS } \\
107,5376 \text { BT }\end{array}$ & $\begin{array}{l}\text { - Berada di daerah perkotaan } \\
\text { - Sepadan sungai dimanfaatkan } \\
\text { untuk perkebunan pisang, pohon } \\
\text { bambu dan terdapat rerumputan } \\
\text { tinggi }\end{array}$ \\
\hline 5 & Sungai Cimeta Citarum & $\begin{array}{r}-6,9204 \text { LS } \\
107,6083 \text { BT }\end{array}$ & $\begin{array}{l}\text { - Berada di daerah perkotaan dan } \\
\text { pemukiman } \\
\text { - Sepadan sungai sudah ditembok } \\
\text { - Terdapat sampah penduduk } \\
\text { - Terrace kota }\end{array}$ \\
\hline 6 & Sungai Cimeta & $\begin{array}{r}-6,8158 \text { LS } \\
107,3221 \text { BT }\end{array}$ & $\begin{array}{l}\text { - Berada di daerah hutan dan } \\
\text { perkebunan } \\
\text { - Sepadan sungai ditumbuhi } \\
\text { tumbuhan air yang cukup lebat } \\
\text { - Terdapat sampah penduduk }\end{array}$ \\
\hline 7 & Sungai Cikao & $\begin{array}{r}-6,5112 \text { LS } \\
107,412 \text { BT }\end{array}$ & $\begin{array}{l}\text { - } \quad \text { Berada di daerah pesawahan } \\
\text { - } \quad \text { Sepadan sungai ditumbuhi } \\
\text { tumbuhan air dan pohon bambu } \\
\text { - } \quad \text { Erosi sepadan sungai cukup tinggi }\end{array}$ \\
\hline
\end{tabular}

Pengambilan sampel air dilakukan di tujuh stasiun penelitian sepanjang Sungai Citarum (meliputi daerah hulu, tengah, dan hilir). Pengujian sampel air dilakukan untuk parameter suhu, kekeruhan, TSS, DO, dan BOD. Proses analisa data kualitas air dilakukan untuk masingmasing parameter dan dibandingkan dengan klasifikasi mutu air menurut Peraturan Pemerintah Nomor 82 Tahun 2001.

Penerapan model matematika StreeterPhelps mengacu pada Keputusan Menteri Negara Lingkungan Hidup Nomor 110 Tahun 2003, salah satu metode yang digunakan untuk mengetahui nilai defisit serta menggambarkan pola sebaran konsentrasi oksigen terlarut. Bentuk persamaan model Streeter-Phelps ${ }^{(16)}$

Penentuan laju oksidasi senyawa organik dengan formulasi :

\section{Error! Reference source not}

\section{found.}

Keterangan

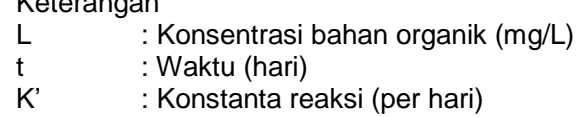

Untuk selanjutnya perhitungan nilai $K^{\prime}$ dengan metode least square berdasarkan hasil pengamatan laboratorium. Penentuan laju reaerasi dengan formulasi :

\section{Error! Reference source not}

found.

$K^{\prime} 2=\frac{294(D L \times U)^{1 / 2}}{H^{3 / 2}}$

Error! Reference source not found.

Keterangan: 


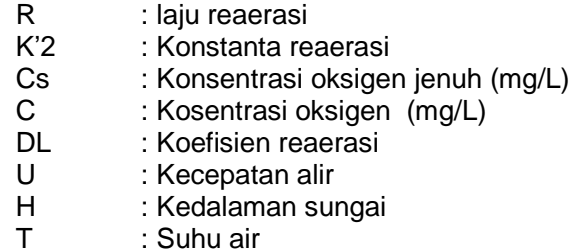

Penentuan defisit DO terendah yang dicapai akibat beban yang diberikan pada aliran tersebut (Dc), dengan formulasi :

$D c=\frac{K^{\prime}}{K_{2}^{\prime}}$ Lo $e^{-k v t_{e}}$

$t_{c}=\frac{1}{K_{2}^{\prime}-K^{\prime}} \ln \left(\frac{K_{2}^{\prime}}{K^{\prime}}\left[1-\frac{D_{0}\left(K_{2}^{\prime}-K^{\prime}\right)}{K^{\prime} L o}\right]\right)$

$X_{c}=t_{c} v$

$\begin{array}{lll}\begin{array}{c}\text { Keterangan } \\ \text { tc }\end{array} & : \begin{array}{l}\text { waktu yang dibutuhkan untuk mencapai titik } \\ \text { kritik }\end{array} \\ \mathrm{Lo} & : & \begin{array}{l}\text { BOD ultimat pada aliran }(\mathrm{mg} / \mathrm{L}) \\ \mathrm{V}\end{array} \\ \mathrm{V} & : & \begin{array}{l}\text { kecepatan aliran }(\mathrm{m} / \mathrm{dt}) \\ \text { Jarak yang dicapai pada defisit oksigen }\end{array} \\ \mathrm{D}_{0} & : \begin{array}{l}\text { kritis } \\ \text { defisit oksigen pada saat } \mathrm{t}=0 \text {, dengan } \\ \text { formulas } \mathrm{i}\end{array}\end{array}$

Defisit Oksigen = DO Saturasi - DO Terukur...(8)

Penentuan beban maksimum yang diizinkan (La) dengan formulasi :

$\log L a=\log D_{a l l}+\left[1+\frac{K^{\prime}}{K^{\prime}{ }_{2}-K^{\prime}}\left(1-\frac{D_{0}}{D_{a n}}\right)^{0,418}\right] \log \frac{K_{2}^{\prime}}{K^{\prime}}$

Keterangan

$D_{\text {all }}$ : defisit DO yang dijinkan, dengan formulasi
$\mathrm{D}_{\mathrm{all}}=\mathrm{DO}_{\text {jenuh }}-\mathrm{DO}$ baku mutu

Penetuan DO model :

DO Model = DO Saturasi - Defisit Oksigen

\section{HASIL DAN PEMBAHASAN}

\subsection{Kondisi Parameter Fisika-Kimia Sungai Citarum}

Kondisi parameter fisika-kimia di Sungai Citarum selama penelitian disajikan pada Tabel 2. Suhu selama penelitian berkisar antara antara $24,3-29,8^{\circ} \mathrm{C}$. Kondisi suhu sendiri dapat mempengaruhi DO jenuh di perairan tropis yang biasanya tidak melebihi $9 \mathrm{mg} / \mathrm{l}$. Kisaran DO jenuh selama pengamatan adalah 7,47-8,28 $\mathrm{mg} / \mathrm{l}$. Sedangkan kisaran nilai DO lapangan selama penelitian adalah 0-6,79 mg/l. Salah satu penyebab rendahnya konsentrasi $\mathrm{DO}$ dalam perairan adalah tingginya nilai BOD. Nilai BOD di Sungai Citarum selama penelitian berkisar antara 5,53-74,24 mg/l, terlihat nilai BOD di beberapa stasiun penelitian telah melebihi baku mutu nilai BOD di perairan yang hanya sebesar $6 \mathrm{mg} / \mathrm{l}$. Hasil pengukuran TSS di Sungai Citarum berkisar antara 7,5-735,7 mg/l.

Suhu merupakan salah satu parameter kunci model kualitas air di suatu perairan. Aktifitas biologi dan proses kelarutan gas di dalam air sangat bergantung pada kondisi suhu(17). Perubahan suhu akan mempengaruhi kandungan DO dalam suatu perairan, peningkatan suhu perairan sebesar $10^{\circ} \mathrm{C}$ menyebabkan terjadinya peningkatan konsumsi oksigen oleh organisme akuatik sebanyak dua sampai 3 kali lipat ${ }^{(18)}$.

Tabel 2. Kondisi parameter fisika-kimia Sungai Citarum

\begin{tabular}{cccccccc}
\hline Stasiun & $\begin{array}{c}\text { Suhu } \\
\left({ }^{\circ} \mathbf{C}\right)\end{array}$ & $\begin{array}{c}\text { Arus } \\
(\mathbf{m} / \mathbf{s})\end{array}$ & $\begin{array}{c}\text { Kedalaman } \\
(\mathbf{m})\end{array}$ & $\begin{array}{c}\text { Lebar } \\
\text { Sungai } \\
(\mathbf{m})\end{array}$ & $\begin{array}{c}\text { TSS } \\
(\mathbf{m g} / \mathbf{l})\end{array}$ & $\begin{array}{c}\text { DO } \\
(\mathbf{m g} / \mathbf{l})\end{array}$ & $\begin{array}{c}\text { BOD } \\
(\mathbf{m g} / \mathbf{l})\end{array}$ \\
\hline $\begin{array}{c}\text { Baku } \\
\text { Mutu }\end{array}$ & $\mathbf{2 5 - 3 0} \mathbf{1 )}$ & - & - & - & $\mathbf{5 0}^{2)}$ & $\mathbf{3}^{2)}$ & $\mathbf{6}^{2)}$ \\
\hline 1 & 25,8 & 0,37 & 4 & 104 & 95 & 0,95 & 5,53 \\
2 & 25 & 0,56 & 4 & 15 & 88,6 & 6,79 & 25,43 \\
3 & 24,3 & 0,63 & 6 & 4 & 59,6 & 1,58 & 21,01 \\
4 & 28,3 & 0,56 & 5 & 40 & 735,7 & 0,00 & 74,24 \\
5 & 29,8 & 0,17 & 1 & 10 & 112,8 & 5,65 & 40,67 \\
6 & 26,4 & 0,06 & 5 & 10 & 17,4 & 6,59 & 21,44 \\
7 & 29,1 & 0,17 & 5 & 6 & 7,5 & 5,65 & 40,67 \\
\hline Keterangan : ${ }^{1)}$ Poxton $(2006) ;{ }^{2}$ Baku Mutu berdasarkan PP No. 82 Tahun 2001 & &
\end{tabular}


Tingginya nilai BOD di Sungai Citarum mengindikasikan bahwa sungai ini telah mengalami tekanan pemanfaatan yang melebihi daya dukungnya, seperti terjadinya ekstensifikasi dan intensifikasi pertanian, pertumbuhan pemukiman, industri, dan perikanan $(19,20)$. BOD limbah domestik yang masuk ke DAS Citarum bagian hulu diperkirakan berkisar antara 160.000-200.000 ton/hari. Berbeda dengan BOD dari aktifitas industri, diperkirakan sebesar 81.363 ton/hari dan mengalami kenaikan pada tahun 2010 mencapai 109.114 ton/hari. Sedangkan dari aktifitas pertanian yang menimbulkan akumulasi nitrogen dan fosfor di perairan, hasil perhitungan nitrogen dan fosfor yang masuk perairan DAS Citarum Hulu masing-masing berkisar antara 6.460187.852 ton $\mathrm{N}$ per tahun, dan 3.060-21.992 ton $\mathrm{P}$ per tahun (21).

\subsection{Distribusi DO}

DO merupakan parameter penting yang dibutuhkan oleh semua organisme, seperti ikan. Penurunan oksigen terlarut dalam perairan akan sangat berbahaya terutama bagi kehidupan akuatik(22). Kebanyakan ikan pada beberapa perairan tercemar mati bukan karena daya racun bahan buangan secara langsung tetapi karena kekurangan oksigen dalam perairan akibat digunakan untuk proses degradasi bahan organik oleh mikroorganisme(23, 24).

Secara keseluruhan kadar DO di perairan Sungai Citarum berkisar antara 0,00-7,79 mg/l, dengan rata-rata $3,52 \mathrm{mg} / \mathrm{l}$. Kadar yang terendah $(0,00 \mathrm{mg} / \mathrm{l})$ ditemukan di stasiun 4 , sedangkan kadar tertinggi $(7,79 \mathrm{mg} / \mathrm{l})$ ditemukan di stasiun 6. Rendahnya DO di stasiun 4 berkaitan erat dengan tingginya kekeruhan di stasiun tersebut (Gambar 2). Kisaran kekeruhan selama penelitian adalah 30,7-459 NTU(25). Berdasarkan Kepmenkes RI No:416/MENKES/PER/IX/1990 untuk kualitas air bersih, kadar kekeruhan maksimum yang diperbolehkan adalah 25 NTU.

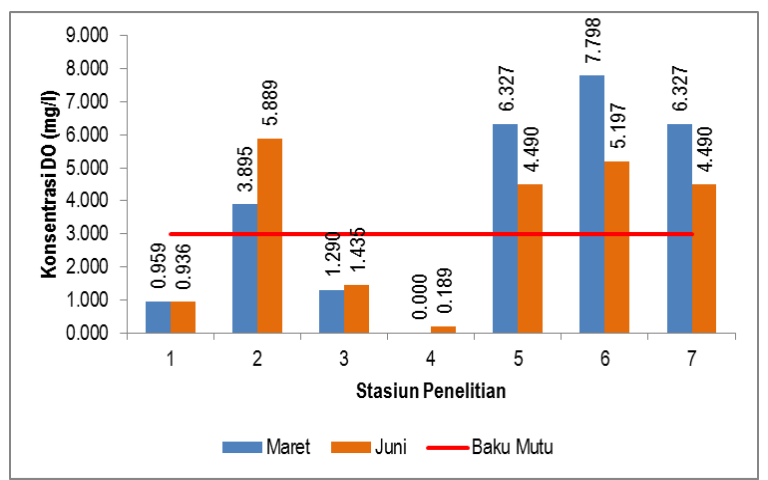

Gambar 2. Distribusi DO selama penelitian

Dari variasi kadar DO di perairan ini menunjukkan bahwa kadar DO yang rendah ditemukan di lokasi pemukiman. Kondisi ini disebabkan oleh bahan organik baik yang berasal dari limbah domestik yang berasal dari pemukiman. Limbah domestik yang berasal dari pemukiman biasanya memiliki beberapa sifat utama yaitu mengadung bakteri, mengandung bahan organik dan padatan tersuspensi sehingga BOD biasanya tinggi, padatan organik dan anorganik yang mengendap di dasar perairan dan menyebabkan DO rendah, terakhir mengandung bahan terapung dalam bentuk suspensi sehingga menghambat laju fotosintesis ${ }^{(26) .}$

\subsection{Respon DO-BOD}

Berdasarkan respon DO-BOD (Gambar 3), terlihat nilai BOD cenderung meningkat di beberapa stasiun penelitian di Sungai Citarum. Kondisi ini sejalan dengan penurunan nilai DO. BOD tertinggi terjadi di stasiun 4 yang merupakan daerah bagian tengah Sungai Citarum. Kondisi ini disebabkan adanya masukan limbah dari pemukiman dan industri, terlihat dari kondisi air sungai yang berwarna hitam dan berbau.

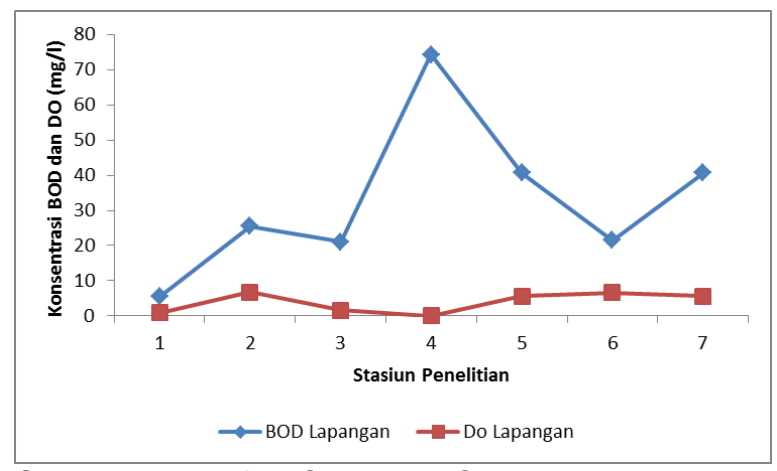

Gambar 3. Profil BOD dan DO selama penelitian

Berdasarkan respon BOD-DO pada Gambar 2 terlihat adanya tiga zona karakteristik yang membedakan potensi kemampuan asimilasi dari Sungai Citarum. Zona reaerasi terdapat pada stasiun 2, 5, 6, dan 7 , yaitu di daerah hulu dan hilir Sungai Citarum. Terlihat dari nilai DO yang berkisar antara 5,65-6,79 mg/l. Nilai DO yang masih diatas baku mutu ini dapat menajdi buffer oksigen yang diperlukan apabila terjadi penambahan limbah organik yang berasal dari kegiatan yang ada di sekitar Sungai Citarum.

Berbeda dengan stasiun 3, yaitu di daerah tengah Sungai Citarum yang masuk ke zona deoksigenasi. Kondisi DO berada pada tarap deplesi oksigen karena oksigen yang masuk mulai tidak sebanding dengan kebutuhan degradasinya, distribusi oksigen di stasiun 2 yang awalnya berada di $6,79 \mathrm{mg} / \mathrm{l}$ turun secara drastis di stasiun 3 ke 1,58 mg/l. Laju 
deoksigenasi bahan organik dari sumber pencemaran menunjukkan bahwa sumber pencemar yang berasal dari Sungai Ciwidey mempunyai laju penurunan oksigen paling tinggi. Hasil penelitian tahun 2010 menyebutkan laju deoksigenasi bahan organik di beberapa anak sungai Citarum seperti Sungai Ciwidey, Sungai Cisangkuy, Sungai Cikapundung, Sungai Cimahi secara berturut turut adalah 0,$177 ; 0,265 ; 0,220 ;$ dan $0,482^{(27)}$. Peningkatan nilai laju deoksigenasi bahan organik diduga akibat peningkatan pencemaran organik. Hasil pengamatan menunjukkan bahwa laju deoksigenasi di daerah S Citarum-Ciwidey dan S. CitarumCicangkri mengalami penurunan yang sejalan dengan peningkatan laju reaerasi.

Zona terakhir adalah zona dekomposisi aktif yang terdapat di stasiun 1 dan 4 . DO di dua stasiun ini bergerak ke titik defisit oksigen kritis karena oksigen yang masuk tidak dapat memenuhi kebutuhan degradasinya. Nilai DO mencapai 0-0,95 mg/l. Kondisi DO yang rendah ini sebagai akibat dari banyaknya bahan organik baik dari limbah domestik yang berasal dari pemukiman dan limbah industri yang berasal dari buangan industri yang ada di sekitar bantaran Sungai Citarum.

Dari hasil analisis DO, terlihat perbandingan nilai DO pada model dan nilai DO lapangan seperti yang terlihat pada Gambar 4. Dari gambar terlihat adanya kesamaan pola yang dibentuk oleh DO model dan DO lapangan, meskipun ada beberapa nilai DO model di beberapa titik yang berbeda dengan nilai DO hasil lapangan.

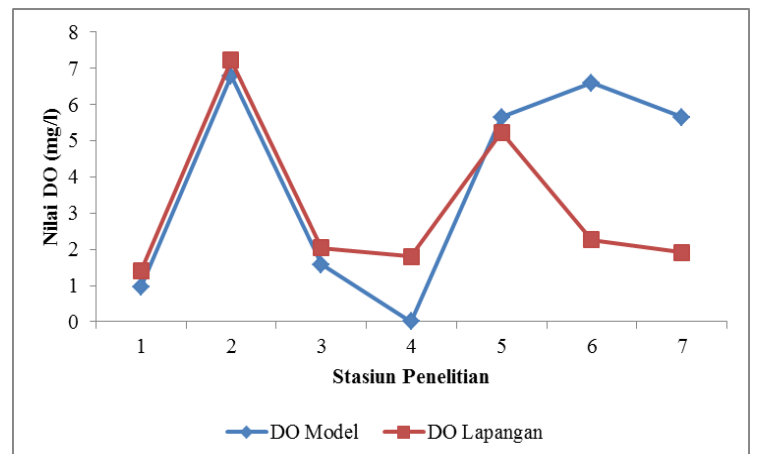

Gambar 4. Perbandingan nilai DO Model dan DO lapangan selama penelitian

Untuk melihat seberapa besar nilai korelasi yang didapat antara nilai DO model dan lapangan tersaji pada Gambar 5. Nilai koefisien korelasi antara DO model dan DO lapangan adalah 0,3796, sedangkan nilai koefisien korelasi nya adalah 0,6161. Koefisien korelasi sendiri merupakan ukuran ketepatan hubungan linear diantara nilai $x$ dan nilai $y$, dimana jika nilainya mendekati 0,6-1 menunjukkan tingkat ketepatan hubungan linear yang sempurna. Korelasi ini dilakukan untuk melihat apakah model yang digunakan sudah bisa merepresentasikan kondisi yang ada di lapangan. Hal ini menjelaskan bahwa antara nilai DO model dan DO lapangan di aliran Sungai Citarum memiliki hubungan yang hampir mendekati.

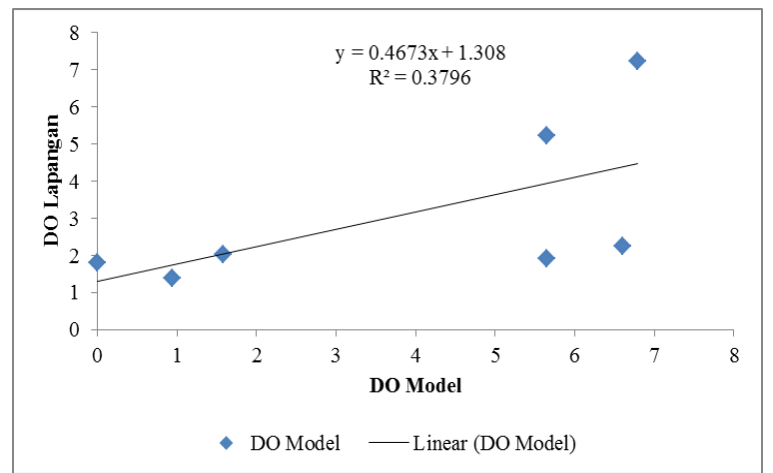

Gambar 5. Korelasi nilai DO model dan DO lapangan selama penelitian

\subsection{Sumberdaya Ikan di Sungai Citarum}

Hasil penelitian di bulan Maret dan Juni 2016 berdasarkan hasil wawancara dan tangkapan nelayan disajikan pada Tabel 3 . Berbeda dengan hasil penelitian (28) di Sungai Citarum, dimana jenis ikan yang ditemukan antara lain Ar-ar (Carassius carassius), golsom (Aequidens goldsaum), nila (Oreochromis niloticus), mujair (Oreochromis mossambicus), betok (Anabas testudineus), lele (Clariasbatrachus), sapu-sapu (Hyposarcus pardalis), gabus (Channa striata) dan sepat (Trichogaster trichopterus). Adanya penurunan keragaman jenis ikan

Sungai Cicangkri seperti terlihat pada Tabel 3 terjadi karena tekanan terhadap lingkungan perairan.

Rekomendasi DO untuk ikan air tawar tropis sendiri adalah $5 \mathrm{mg} / \mathrm{/}^{(7)}$. Dari sekian banyak ikanikan yang ditemukan di Sungai Citarum, ikan nila, mujair, mas dan lele adalah ikan yang dapat hidup di perairan dengan konsentrasi DO 3-5 $\mathrm{mg} /(29,30)$. Sama halnya dengan ikan lele, ikan gabus mampu hidup pada perairan yang minim akan oksigen ${ }^{(31)}$. Ikan ini tergolong ikan yang menyukai tempat gelap dengan dasar berlumpu atau bebatuan. Ikan gabus dan lele memiliki kemampuan bernafas langsung dari udara karena mempunyai organ labirin. Labirin ini berfungsi untuk menyimpan cadangan oksigen yang nantinya bisa digunakan pada saat ikan berada pada daerah atau lingkungan dengan kadar oksigen rendah (32). Sedangkan ikan sapusapu adalah golongan ikan tropis yang dikenal sebagai Plecostomus, jenis ikan ini dapat 
ditemukan pada berbagai wilayah perairan, seperti aliran sungai yang sempit di pegunungan, muara sungai, bahkan pada perairan dengan tingkat pencemaran tinggi(33). Ikan sapu-sapu memiliki kemampuan untuk menghirup udara dari permukaan air pada musim kemarau atau pada saat kandungan DO dalam air rendah ${ }^{(34)}$. Seperti yang terjadi di Sungai Cicangkri, dimana kadar DO hanya berkisar pada $0,00-0,189 \mathrm{mg} / \mathrm{l}$. Ikan yang ditemukan di perairan tersebut adalah ikan sapu-sapu.

Tabel 3. Jenis-jenis ikan yang ditemukan di Sungai Citarum selama penelitian

\begin{tabular}{clcl}
\hline No. & \multicolumn{1}{c}{ Lokasi } & Kisaran DO (mg/l) & \multicolumn{1}{c}{ Jenis Ikan } \\
\hline 1. & Sungai Ciwidey & $0,96-5,889$ & - Nila (Oreochromis niloticus) \\
& & & - Mujair (Oreochromis mossambicus) \\
2. & Sungai Cicangkri & - Lele (Clarias batrachus) \\
3. & Ruas Sungai Cimeta-Cihea & $0,00-0,189$ & - Sapu-sapu (Hyposarcus pardalis) \\
4. Sungai Cimeta & $4,49-7,79$ & - Nila (Oreochromis niloticus) \\
& & & - Mujair (Oreochromis mossambicus) \\
& & $4,49-7,79$ & - Kebogerang (Mystus nigriceps) \\
5. Sungai Cikao & & - Sapu-sapu (Hyposarcus pardalis) \\
& & & - Genggehek(Mystacoleucus marginatus) \\
& & & - Lalawak (Barbodes bramoides) \\
& & $4,49-6,32$ & - Gabus (Channa striata) \\
& & - Mas (Cyprinus carpio) \\
\end{tabular}

Sumber utama oksigen dalam suatu perairan berasal dari proses difusi dari udara bebas dan hasil fotosintesis organisme yang hidup dalam perairan tersebut ${ }^{(24)}$. Kadar DO di perairan sangat bervariasi tergantung suhu, turbulensi air, dan tekanan atmosfer. Semakin besar suhu maka kadar DO akan semakin kecil(18). $^{(18)}$

Masuknya bahan-bahan buangan organik, menjadi penyebab utama berkurangnya $\mathrm{DO}$ di perairan Sungai Citarum. Konsentrasi oksigen terlarut yang aman bagi kehidupan ikan diperairan sebaiknya harus diatas titik kritis. Pada saat penelitian di beberapa stasiun penelitian nilai DO mencapai kurang dari 2 $\mathrm{mg} / \mathrm{l}$, dan ini sangat membahayakan bagi kehidupan dan pertumbuhan ikan. Konsentrasi DO minimun di perairan adalah sebesar 2 $\mathrm{mg} / \mathrm{l}$ karena masih cukup menunjang secara normal komunitas akuatik di perairan (35). Sebagian besar spesies ikan akan menoleransi penurunan nilai oksigen di bawah nilai minimum untuk waktu singkat, namun dalam periode waktu yang lama penurunan oksigen akan menyebabkan ikan menjadi stres ${ }^{(8)}$.

Kondisi DO yang rendah juga bisa berakibat pada kematian dan pertumbuhan dari ikan, kisaran DO 0,3-1,0 mg/l akan menyebabkan kematian pada ikan apabila berlangsung lama, sedangkan kisaran DO 1,0$5,0 \mathrm{mg} / \mathrm{l}$ akan membuat pertumbuhan ikan menjadi lambat ${ }^{(11)}$. Menanggapi konsentrasi rendah oksigen terlarut dalam air, ikan sendiri dapat merespon dalam dua cara. Yang pertama, aliran darah dapat ditingkatkan dengan membuka lamellae lanjut sekunder untuk meningkatkan area pernapasan yang efektif, yang kedua konsentrasi sel darah merah dapat ditingkatkan dengan membawa oksigen dari darah per satuan volume. Yang terakhir ini dapat dicapai dengan mengurangi volume plasma darah (misalnya dengan meningkatkan laju aliran urin) dalam jangka pendek, dengan melepaskan sel darah ekstra dari limpa dalam jangka panjang ${ }^{(36)}$.

Beberapa ikan yang hidup di Sungai Citarum adalah ikan yang mampu bertahan pada kandungan DO kurang dari $4 \mathrm{mg} / \mathrm{l}$, terutama ikan-ikan yang mempunyai alat pernafasan tambahan yang memungkinkan mengambil oksigen langsung dari udara bebas seperti lele dan gabus. Kemunculan ikan sapu-sapu di Sungai Citarum, dimana populasinya lebih tinggi dibanding ikan jenis lain bisa dijadikan indikator telah terjadi pencemaran lingkungan, seperti penelitian di Sungai Pabelan Kartasura( ${ }^{(30)}$. Ikan sapu-sapu sendiri termasuk jenis ikan yang tahan terhadap kondisi perairan yang tercemar dengan kadar DO yang rendah.

\section{KESIMPULAN}

Penggunaan model Streeter \& Phelps dalam pendugaan pola sebaran konsentrasi oksigen terlarut (DO) selama penelitian sangat ditentukan oleh kondisi hidrodinamika dan beban masukan yang berbeda tiap aliran sungainya. Beban masukan berasal dari masuknya bahan-bahan buangan organik di 
perairan Sungai Citarum. Kondisi DO rendah ini juga berpengaruh pada keberadaan, pertumbuhan dan kelangsungan hidup ikan di Sungai Citarum sehingga berakibat telah terjadi pengurangan jenis-jenis ikan.

\section{PERSANTUNAN}

Tulisan ini merupakan kontribusi dari kegiatan riset 'Teknologi Pengendalian Pencemaran dan Modeling Kualitas Air di DAS Citarum, Jawa Barat. Ucapan terima kasih juga disampaikan kepada Dr. Joni Haryadi, M.Sc selaku Kepala Balai dan Dyah Ika Kusumaningtyas, S.Si yang telah membantu dalam pengambilan data.

\section{DAFTAR PUSTAKA}

1. Lee, C.D., S.B. Wang, and C.L. Kuo. (1978). Benthic Macroinvertebrates and Fish as Biological Indicator of Water Quality Reference to Community. Diversity Development Countries. Bangkok.

2. Nontji, A. (1984). Biomassa dan Produktivitas Fitoplankton di Perairan Teluk Jakarta serta Kaitannya dengan Faktor-Faktor Lingkungan (disertasi). Bogor: Program Pascasarjana Institut Pertanian Bogor.

3. Mays, L.W. (1996). Water Resources Handbook. McGraw-Hill. New York.

4. Odum, E.P. (1973). Fundamentals of Ecology. Third Edition.

5. Gower, A. M., (1980). Water Quality in Catchment Ecosystems. John Willey \& Sons. New York.

6. Stiff, M. J, N.G. Cartwright, and R.I. Crane, (1992). Environmental Quality Standards for Dissolved Oxygen. NRA R\&D Note. 130.

7. Buttner, J.K., R.W. Soderberg, and D.E. Terlizzi, (1993). An Introduction to Water Chemistry in Freshwater Aquaculture. NRAC Fact Sheet No. 170.

8. Svobodova Z, Richard Lioyd, Jana Machova, dan Blanka Vykusova, (1993). Water Quality and Fish Health. EIPAC Technical Paper. FAO Fisheries Department.

9. Novotny, V and H. Olem. (1994). Water Quality, Prevention, Identification and Management of Diffuse Pollution. Van Nostrans Reinhold. New York.

10. Kimbal, J.W. (1988). Biologi. Penerbit Erlangga, Jakarta.
11. Malya, Y.J. (2007). The Effects of Dissolved Oxygen on Fish Growth in Aquaculture. UNU-Fisheries Training Programme. 30 pp.

12. Suyanto, S.R. (2008). Budidaya Ikan Lele (edisi revisi). Penebar Swadaya. Jakarta. 92 hal.

13. Kurniasih, N. (2002). Pengelolaan DAS Citarum Berkelanjutan. Jurnal Teknologi Lingkungan. 3(2) : 159-164.

14. BP2KSI. (2015). Penelitian Pemulihan Populasi Ikan dan Rehabilitasi Habitat Sumberdaya Ikan di DAS Citarum, Jawa Barat. Laporan Tahunan Penelitian BP2KSI 2015 (tidak dipublikasikan).

15. Streeter, H. W. and E. B. Phelps, (1925). A study of The Pollution and Natural Purification of The Ohio River: Washington, U.S. Public Health Service, Public Health Bull. $146: 75$.

16. Davis, M. L. dan Cornwell, D. A. (1991). Introduction to Environmental Engineering . Second edition. Mc-Graw-Hill, Inc. New York.

17. Astono, W., M.S. Saeni, B.W. Lay, dan S. Soemarto, (2008). Pengembangan Model DO-BOD Dalam Pengelolaan Kualitas Air Sungai Ciliwung. Forum Pascasarjana. 31(1) : 37-44.

18. Effendi, H. (2003). Telaah Kualitas Air bagi Pengelolaan Sumber Daya dan Lingkungan Perairan. Cetakan Kelima. Yogyakarta : Kanisius

19. Bukit, N.T dan I.A. Yusuf (2002). Beban Pencemaran Limbah Industri dan Status Kualitas Air Sungai Citarum. Jurnal Teknologi Lingkungan. 3(2) : 98-106.

20. Salim, H. (2002). Beban Pencemaran Limbah Domestik dan Pertanian di DAS Citarum. Jurnal Teknologi Lingkungan. 3(2) : 107-111.

21. Komarawidjaja, W. (2005). Status Makro Invertebrata pada Perairan DAS Citarum Hulu yang Tercemar. Jurnal Teknologi Lingkungan. 6(3) : 446-451.

22. Manalu, J. (2012). Model Pengelolaan Teluk Youtefa Terpadu Secara Berkelanjutan. Disertasi. Sekolah Pasca Sarjana. Institut Pertanian Bogor.

23. Jones, H.R.E. 1964. Fish and River Pollution. Buther Worth. London: $230 \mathrm{pp}$ 
24. Salmin. (2000). Kadar Oksigen Terlarut di Perairan Sungai Dadap, Goba, Muara Karang dan Teluk Banten. Dalam : Foraminifera Sebagai Bioindikator Pencemaran, Hasil Studi di Perairan Estuarin Sungai Dadap, Tangerang (Djoko P. Praseno, Ricky Rositasari dan S. Hadi Riyono, eds.) P3O - LIPI hal 42 - 46.

25. BP2KSI. (2016). Teknologi Pengendalian Pencemaran dan Modelling Kualitas Perairan di DAS Citarum, Jawa Barat.

26. Supriharyono. (2002). Pelestarian dan pengelolaan sumber daya alam di wilayah pesisir tropis. Jakarta

27. Harsono, E. (2010). Evaluasi Kemampuan Pulih Diri Oksigen Terlarut Air Sungai Citarum Hulu. LIMNOTEK. 12(1) :17-36.

28. Budiman, B.T.P., Y. Dhahiyat, dan Hamdani, H. (2012). Bioakumulasi Logam Berat Pb (Timbal) dan Cd (Kadmium) Pada Daging Ikan yang Tertangkap di Sungai Citarum Hulu. Jurnal Perikanan dan Kelautan. 3(4) : 261-270.

29. Permatasari, D.W. 2012. Kualitas Air pada Pemeliharaan Ikan Nila Oreochromis sp. Intensif di Kolam Departemen Budidaya Perairan, Institut Pertanian Bogor. Skripsi. Departemen Budidaya Perairan. Fakultas Perikanan dan IImu Kelautan. Institut Pertanian Bogor. 23 hal.

30. Rudiyanti, S dan A.D. Ekasari. 2009. Pertumbuhan dan Survival Rate Ikan Mas (Cyprinus carpio Linn) pada Berbagai Konsentrasi Pestisida Regent 0,3 G. Jurnal Saintek Perikanan.5(1) : $49-54$.
31. Extrada, E., H.T. Ferdinand, dan Yulisman. 2013. Kelangsungan Hidup dan Pertumbuhan Benih Ikan Gabus (Channa striata) pada Berbagai Tingkat Ketinggian Air Media Pemeliharaan. Jurnal Akuakultur Rawa Indonesia. 1(1) : 1003-114.

32. Purnamawati dan D. Djokosetiyanto. (2017). Kinerja Pertumbuhan Ikan Gabus (Channa Striata Bloch.) pada Lahan Pasang Surut melalui Rekayasa Kualitas Air.

33. Geerinckx, T., M. Brunain, A. Herrel, P. Aerts and D. Adriaens. (2007). A Head a Suckermouth : A Functional-Morphological Study of The Head of The Suchkermouth Armoured Catfish Ancistrus cf. Triradiatus (Loricariidae, Siluriformes). Diakses tanggal 28 Oktober 2017. http://naturalsciences.be.

34. Armbruster, J.W., $1998 . \quad$ Phylogenetic relationships of the suckermouth armored catfishes of the Rhinelepis group (Loricariidae: Hypostominae). Copeia. (3):620-636.

35. Pescod, M.B., (1973). Investigation of Rational Effluen and Stream Standard for Tropical Countries. London : AIT.

36. Saputro, A., Hariyatmi, dan E. Setyaningsih. (2012). Identifikasi Kualitatif Kandungan Logam Berat $(\mathrm{Pb}, \mathrm{Cd}, \mathrm{Cu}$, dan $\mathrm{Zn})$ pada Ikan Sapu-Sapu (Hypostomus plecostomus) di Sungai Pabelan Kartasura Tahun 2012. Seminar Nasional IX Pendidikan Biologi FKIP UNS 2012 : 416-420. 
